1 Dowd PM, Martin MFR, Cooke ED, et al. Treatment of Raynaud's phenomenon by intravenous infusion of prostacyclin $\left(\mathrm{PGI}_{2}\right) . \mathrm{Br} f$ Dermatol 1982;106:81-9.

2 Belch JJF, Drury JK, Cappell H, et al. Intermittent epoprostenol (prostacyclin) infusion in patients with Raynaud's syndrome. Lancet 1983:ز:313-4.

Meyrick Thomas RH, Rademaker M, Grimes SM, et al Nifedipine in the treatment of Raynaud's phenomenon patients with systemic sclerosis. $\mathrm{Br} \mathcal{Z}$ Dermatol 1987;117:237-41.

4 Rademaker M, Thomas RHM, Provost G, Beacham JA, Cooke ED, Kirb JDT. Prolonged increase in digital blood flow following iloprost infusion in Jatients with systemic sclerosis. Postgrad Med f 1987;63:617-20.

5 Sub-committee for Scleroderma Criteria of the American Rheumatism

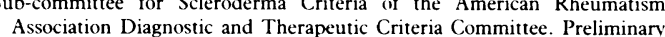
criteria for the classification of systemic sclerosis (scleroderma). Arthrit Rheum 1980:23:581-90.

6 Maricq HR. Widefield capillary microscopy. Technique and rating scale for abnormalities seen in scleroderma and related disorders. Arthritis Rheum 1981;24:1159-65

Cooke ED, Bowcock SA, Smith AT. Photoplethysmography of the distal pulp in the assessment of the vasospastic hand. Angiology 1985;36:33-9.

Almond NE, Jones DP, Cooke ED. Good quality photoplethysmograph signals derived from a laser Doppler flowmeter preliminary studies of the two outputs obtained simultaneously from the finger. $f$ Biomed Eng 1988;10:458-62.

9 Cooke ED, Bowcock SA, Smith AT. A mathematical model for the vascular behaviour of the hands in response to cold stress. Vascular Medicine 1985;3:98-104.

10 Bennett T, Hosking DJ, Hampton JR. Cardiovascular responses to lower bod negative pressure in normal subjects and in patients with diabetes mellitus.

11 Smith CD, McKendry R. Controlled trial of nifedipine in the treatment of Raynaud's phenomenon. Lancet 1982;ii:1299-301.

12 Winston EL, Pariser KM, Miller KB, et al. Nifedipine as a therapeutic modality for Raynaud's phenomenon. Arthritis Rheum 1983;26:1177-80.

13 Rodeheffer RJ, Rommer JA, Wigley F, Smith CK. Controlled double-blınd

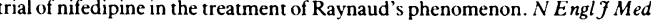
1983;308:880-3.

14 Souza J, Kraus A, Gonzalez-Amaro R, Alarcon-Segovia D. Effect of the calcium channel blocker nifedipine on Raynaud's phenomenon. A controlled double-blind trial. F Rheumatol 1984:11:362-4

15 Kahar A, Weber S, Amor B, et al. Controlled trial of nifedipine in the treatment of Raynaud's phenomenon. Rev Rhum Mal Osteoartic 1982;49: $337-43$

16 Bravard P, Moore N. Nifedipine for Raynaud's phenomenon. Lance $1983 ; \mathrm{i}: 130-1$.

17 Sarkozi J, Bookman AAM, Mahon W, et al. Nifedipine in the treatment of idiopathic Raynaud's syndrome (IRS). Arthritis Rheum 1984;27 (suppl):27. 18 Rustin MHA, Cooke ED, Bowcock SA, Kirby JDT. Nifedipine for Raynaud's phenomenon. Lancet 1983;i:130.

19 Kenny J. Calcium channel blocking agents and the heart. Br Med $\mathcal{J}$ 1985;291:1150-2

20 Lindsey G, McCullough RG, Seaman J, Hawkins R, Weil J, Steigerwald J. Nifedipine may be harmful in the treatment of Raynaud's phenomeno secondary to systemic sclerosis. Arthritis Rheum 1984;27 (suppl):18.

21 Furchgott RF, Zawadzki JV. The obligatory role of endothelial cells in the relaxation of arterial smooth muscle. Nature 1980;288:373-6.

22 Singer HA, Peach MJ. Endothelium-dependent relaxation of rabbit aorta 1 and 2. F Pharmacol Exp Ther 1983;226:790-801.

23 Aldoori M, Campbell WB, Dieppe PA. Nifedipine in the treatment of Raynaud's syndrome. Cardiovasc Res 1986;20:466-70.

24 Rademaker MT, Kirby JDT, Kovacs IB. Altered in-vitro clotting and thrombolysis after oral nifedipine in normal volunteers. Angiology (in press.)

25 Jarrett PEM, Morland M, Browse NL. Treatment of Raynaud's phenomenon by fibrinolytic enhancement. BrMed f 1978;ii:523-5.

26 Blunt RJ, George AJ, Hurlow RA, Strachan CJL, Stuart J. Hyperviscosity and thrombotic changes in idiopathic and secondary Raynaud's syndrome. $\mathrm{Br} \mathcal{F}$ Haematol 1980;45:651-8.

\title{
Growth in utero, blood pressure in childhood and adult life, and mortality from cardiovascular disease
}

\author{
D J P Barker, C Osmond, J Golding, D Kuh, M E J Wadsworth
}

\begin{abstract}
In national samples of 992110 year olds and 3259 adults in Britain systolic blood pressure was inversely related to birth weight. The association was independent of gestational age and may therefore be attributed to reduced fetal growth. This suggests that the intrauterine environment influences blood pressure during adult life. It is further evidence that the geographical differences in average blood pressure and mortality from cardiovascular disease in Britain partly reflect past differences in the intrauterine environment.
\end{abstract}

Within England and Wales 10 year olds living in areas with high cardiovascular mortality were shorter and had higher resting pulse rates than those living in other areas. Their mothers were also shorter and had higher diastolic blood pressures. This suggests that there are persisting geographical differences in the childhood environment that predispose to differences in cardiovascular mortality.

\section{Introduction}

Two lines of evidence suggest that an adverse environment during early childhood has an important effect on the later risk of cardiovascular disease. Firstly, height, which is determined largely by growth in early childhood,' has been shown to be inversely related to cardiovascular mortality in prospective studies in Norway, ${ }^{2}$ Finland, ${ }^{3}$ and among male civil servants in London. ${ }^{4}$ There is also a close inverse correlation between average height and cardiovascular mortality in the counties of England and Wales (Barker et al, unpublished). Secondly, there is a close relation between differences in cardiovascular mortality between one part of England and Wales and another and differences in infant mortality 60 and more years ago. ${ }^{56}$ The geographical distribution of cardiovascular disease is more closely related to neonatal and maternal death rates in the past than to postneonatal rates. ${ }^{6}$ This points to the importance of the environment during intrauterine rather than early postnatal life.

Blood pressure has been suggested as one link between the intrauterine environment and risk of cardiovascular disease. ${ }^{6}$ We have therefore examined the relations among blood pressure, pulse rate, and intrauterine influences, as measured by birth weight, gestational period, mother's height, and mother's blood pressure. To do this we have used data from two large national samples, one of children aged 10 and another of adults aged 36 .

We used geographical comparisons within England and Wales to examine the relation between intrauterine influences and cardiovascular disease. We compared geographical variations in mothers' heights and blood pressures, and in the birth weights of their children, with differences in cardiovascular mortality.

\section{Subjects and methods}

1970 Cohort-Roughly $97.5 \%$ of all births in Great Britain during one week in April 1970 were included in the British births survey. ${ }^{7.9}$ Information recorded at around the time of birth included birth weight, gestational period, and mother's blood pressure at first attendance at the antenatal clinic. Social class at birth was derived from father's occupation. Surviving children were followed up at 10 years when they were examined by clinical medical officers. Their heights, weights, blood pressures, and pulse rates were measured by standardised procedures. Mothers' heights were also recorded. Blood pressure was measured towards the end of the examination by using a sphygmomanometer. The cuff size, which was recorded, was sufficient to encircle the upper arm completely and cover two thirds of its length. Diastolic
Correspondence to:

Professor Barker. 
pressure was recorded at the fourth Korotkoff sound. Recordings were usually rounded to the nearest $10 \mathrm{~mm} \mathrm{Hg}$. Pulse rate was recorded over one minute at the beginning and end of the examination after the child had been left to settle for two minutes. We took the lower of the two recordings as the resting rate. Our analysis of these data is based on the 9921 children born in England and Wales for whom there were complete data.

1946 Cohort-The Medical Research Council's national survey of health and development is a follow up study from birth of 5362 people born in $1946 .^{10}$ The sample was taken from births in England, Wales, or Scotland during the week 3-9 March and comprises all single, legitimate births to wives of non-manual and agricultural workers and a randomly selected one in four sample of single, legitimate births to manual workers. Information on birth weight and mother's height was obtained from maternity records and by health visitors eight weeks after the birth. At the last data collection, when the study population was aged 36 , contact was made with 3259 men and women, representing $86 \%$ of the sample still alive and resident in England, Wales, or Scotland. At that time heights, weights, blood pressures, and pulse rates were measured by specially trained nurses. Blood pressure was measured at the end of an interview, during which the subject had been seated for a median of 100 minutes. Measurements were taken on the left arm by using the Hawksley random zero sphygmomanometer and a regular size $(12 \times 23 \mathrm{~cm})$ upper arm cuff. Systolic and diastolic (phase $\mathrm{V}$ ) pressures were recorded and corrected for arm circumference.

Cardiovascular mortality - The Office of Population Censuses and Surveys made available extracts from all death certificates in England and Wales during 1968-78, the period covered by the eighth revision of the International Classification of Diseases." Our

TABLE I - Mean systolic blood pressures $(\mathrm{mm} \mathrm{Hg})$ of 992110 year olds stratified by thirds of weight and birth weight

\begin{tabular}{|c|c|c|c|c|c|c|c|c|}
\hline \multirow[b]{2}{*}{ Birth weight ${ }^{\star}$} & \multicolumn{4}{|c|}{$\begin{array}{c}\text { Boys } \\
\text { Current weight }(\mathrm{kg})\end{array}$} & \multicolumn{4}{|c|}{$\begin{array}{c}\text { Girls } \\
\text { Current weight }(\mathrm{kg})\end{array}$} \\
\hline & $<29 \cdot 7$ & $29 \cdot 7-33 \cdot 9$ & $>33.9$ & All boys & $<29 \cdot 7$ & $29 \cdot 7-34 \cdot 6$ & $>34 \cdot 6$ & All girls \\
\hline Lowest & $95 \cdot 8$ & $98 \cdot 0$ & 101.4 & $98 \cdot 5$ & $96 \cdot 0$ & $98 \cdot 6$ & $101 \cdot 2$ & $98 \cdot 6$ \\
\hline Middle & $96 \cdot 2$ & $97 \cdot 4$ & $100 \cdot 9$ & $98 \cdot 1$ & $95 \cdot 4$ & $97 \cdot 7$ & 100.9 & 98.0 \\
\hline Highest & $95 \cdot 7$ & $97 \cdot 7$ & $100 \cdot 8$ & $98 \cdot 1$ & $94 \cdot 7$ & $97 \cdot 3$ & $99 \cdot 8$ & $97 \cdot 3$ \\
\hline All & $95 \cdot 9$ & $97 \cdot 7$ & $101 \cdot 0$ & $98 \cdot 2$ & $95 \cdot 3$ & $97 \cdot 9$ & $100 \cdot 6$ & $98 \cdot 0$ \\
\hline
\end{tabular}

${ }^{\star}$ Boys: Lower tertiles of birth weight 3030,3230 , and $3320 \mathrm{~g}$; upper tertiles 3430,3630 , and $3710 \mathrm{~g}$. Girls: Lower tertiles of birth weight 2980,3090 , and $3180 \mathrm{~g}$; upper tertiles 3350,3490 , and $3540 \mathrm{~g}$.

Numbers of subjects in each cell within table ranged from 499 to 584 ; standard errors ranged from 0.42 to 0.51

TABLE II-Mean systolic blood pressures ( $\mathrm{mm} \mathrm{Hg}$ ) of 1625 men and 1634 women at age 36 stratified by thirds of weight and birth weight

\begin{tabular}{|c|c|c|c|c|c|c|c|c|}
\hline \multirow[b]{2}{*}{ Birth weight ${ }^{\star}$} & \multicolumn{4}{|c|}{$\begin{array}{c}\text { Men } \\
\text { Current weight }(\mathrm{kg})\end{array}$} & \multicolumn{4}{|c|}{$\begin{array}{l}\text { Women } \\
\text { Current weight }(\mathrm{kg})\end{array}$} \\
\hline & $<71 \cdot 1$ & $71 \cdot 1-80 \cdot 0$ & $>80 \cdot 0$ & All men & $<56.6$ & $56 \cdot 6-64 \cdot 5$ & $>64 \cdot 5$ & All women \\
\hline Lowest & $123 \cdot 2$ & $124 \cdot 2$ & $124 \cdot 6$ & $124 \cdot 0$ & $118 \cdot 7$ & $117 \cdot 3$ & $120 \cdot 2$ & $118 \cdot 6$ \\
\hline Middle & $122 \cdot 2$ & $121 \cdot 2$ & $125 \cdot 6$ & $122 \cdot 8$ & $117 \cdot 5$ & $115 \cdot 0$ & $117 \cdot 1$ & $116 \cdot 7$ \\
\hline Highest & $121 \cdot 3$ & $119 \cdot 8$ & $123 \cdot 2$ & $121 \cdot 5$ & $116 \cdot 8$ & $115 \cdot 3$ & $118 \cdot 6$ & $116 \cdot 7$ \\
\hline All & $122 \cdot 4$ & $122 \cdot 0$ & $124 \cdot 4$ & $122 \cdot 9$ & $117 \cdot 8$ & $116 \cdot 1$ & $118 \cdot 6$ & $117 \cdot 4$ \\
\hline
\end{tabular}

${ }^{\star M e n}$ : Lower tertiles of birth weight 3180,3200 , and $3410 \mathrm{~g}$; upper tertiles 3520,3770 , and $3750 \mathrm{~g}$. Women: Lower tertiles of birth weight 3070,3180 , and $3180 \mathrm{~g}$; upper tertiles 3410,3520 , and $3640 \mathrm{~g}$.

Numbers of subjects in each cell within table ranged from 121 to 236 ; standard errors ranged from 0.96 to 1.38 .

TABLE III - Mean systolic blood pressures of 10 year olds stratified by gestational age

\begin{tabular}{lccccc}
\hline & \multicolumn{5}{c}{ Gestation (weeks) } \\
\cline { 2 - 6 } & $\leqslant 36$ & $37-$ & $39-$ & $\geqslant 41$ & All \\
\hline $\begin{array}{l}\text { Mean systolic pressure }(\mathrm{mm} \mathrm{Hg}) \\
\text { No of children }\end{array}$ & $98 \cdot 1$ & $98 \cdot 4$ & $98 \cdot 2$ & $98 \cdot 1$ & $98 \cdot 2$ \\
\hline
\end{tabular}

analysis is based on cardiovascular mortality at ages 35-74 in both sexes combined. Cardiovascular disease was defined as ischaemic heart disease and stroke, ICD ( 8 th revision) codes $410-414$ and 431-438. Rates were calculated for each of the 80 county boroughs, 15 London boroughs, and 59 administrative counties. They were based on population data from the 1971 census and expressed as standardised mortality ratios.

\section{Results}

\section{BLOOD PRESSURE AND PULSE RATE}

Among the 10 year old children in the 1970 cohort both systolic blood pressure and diastolic blood pressure were positively related to pulse rate. Regression analysis showed that an increase of $10 \mathrm{~mm} \mathrm{Hg}$ in systolic pressure was associated with an increase in pulse rate of 0.7 beat $/ \mathrm{min}$ in boys $(95 \%$ confidence interval 0.4 to 0.9$)$ and $0.9 \mathrm{beat} / \mathrm{min}$ in girls $(0.6$ to $1 \cdot 1)$. There was a similar relation among the 36 year old adults from the 1946 cohort, the corresponding figures being an increase of 1.2 beats $/ \mathrm{min}$ in men ( $95 \%$ confidence interval 0.9 to 1.6 ) and 0.9 beat $/ \mathrm{min}$ in women $(0.6$ to 1.2$)$. The mean pulse rate was higher in girls $(79.4$ beats/min) than boys $(76.3$ beats $/ \mathrm{min})$ and higher in women $(73.0$ beats/min $)$ than men $(70.9$ beats $/ \mathrm{min}$ ).

\section{BLOOD PRESSURE, PULSE RATE, AND BIRTH WEIGHT}

There was an inverse relation between systolic blood pressure at age 10 and birth weight. Systolic pressure was also related to current weight but in the opposite direction. These relations are shown in table I, which gives mean systolic pressures with subjects divided into three roughly equal groups by birth weight within each third of body weight. Among boys within each body weight group mean systolic pressure fell by around $0.38 \mathrm{~mm} \mathrm{Hg}$ from the lowest to the highest birthweight group ( $95 \%$ confidence interval -0.04 to $0 \cdot 80)$. Among girls the fall was $1.32 \mathrm{~mm} \mathrm{Hg}(95 \%$ confidence interval 1.03 to 1.61 ). There was no similar trend for diastolic pressure.

There was a stronger inverse relation between systolic pressure at age 36 and birth weight. As before, systolic pressure was also related to current weight. These relations are shown in table II, which gives mean systolic pressures with men and women divided into three roughly equal groups by birth weight within each third of body weight. Because birth weight was recorded only to the nearest quarter of a pound $(113 \mathrm{~g})$ there is some variation in the numbers of subjects in each cell within table II. Among men within each body weight group mean systolic pressure fell by $2.57 \mathrm{~mm} \mathrm{Hg}$ from the lowest to the highest birthweight group ( $95 \%$ confidence interval 0.98 to $4 \cdot 16)$. Among women the fall was $1.83 \mathrm{~mm} \mathrm{Hg}(0.28$ to 3.39$)$. There was no similar trend for diastolic pressure.

Both at 10 and 36 years of age pulse rate was weakly inversely related to birth weight. At neither age was this significant at the $5 \%$ level.

Table III shows mean systolic blood pressures at 10 years of age stratified by completed weeks of gestation. Mean pressures were similar at all gestational periods. Hence the inverse relation with birth weight was not the result of a shortened gestational period. There were no data on length of gestation for the adults.

BLOOD PRESSURE, PULSE RATE, AND MOTHER'S HEIGHT

Table IV shows the mean systolic blood pressures and pulse rates of the adults with subjects divided into three roughly equal groups according to maternal height. Between the groups with the shortest and tallest mothers systolic pressure fell by $2.2 \mathrm{~mm} \mathrm{Hg}$ ( $95 \%$ confidence interval $0 \cdot 4$ to $4 \cdot 1$ ) among men and by $1.0 \mathrm{~mm} \mathrm{Hg}(95 \%$ confidence interval -0.9 
to 3.0) among women. Standardisation to allow for the subjects' weight increased the differences. Falls in diastolic pressure between the groups were smaller than falls in systolic pressure. Mean pulse rates showed small differences with maternal height, and these disappeared after allowing for the subjects' height. Among the 10 year olds blood pressure and mother's height were not related.

BLOOD PRESSURE, PULSE RATE, AND MOTHER'S BLOOD PRESSURE

Mothers' blood pressures were not recorded for the 36 year olds. Among the 10 year olds mean systolic pressure and pulse rates varied with mothers' systolic and diastolic pressures measured at first attendance at the antenatal clinic. Table $\mathrm{V}$ gives the results for diastolic pressure, with mothers divided into four groups. Rounding of results led to many pressures being recorded as $70 \mathrm{~mm} \mathrm{Hg}$. Between the groups of mothers with the lowest and highest pressures the children's systolic pressure rose by $2.0 \mathrm{~mm} \mathrm{Hg}(95 \%$ confidence interval 1.0 to 3.0 ) and pulse rate by 1.0 beat $/ \mathrm{min}(95 \%$ confidence interval 0.1 to 1.9$)$. The results were similar for boys and girls. Adjustment for mothers' blood pressure made little difference to the relation between birth weight and children's blood pressure.

\section{CARDIOVASCULAR MORTALITY}

The number of adult subjects was too small to allow examination of differences in their variables among the 154 areas of England and Wales. In order to examine the geographical distribution of variables in the 1970 cohort we ordered the 154 areas according to standardised mortality ratios from cardiovascular disease. We derived five groups of areas with increasing cardiovascular mortality and roughly similar

TABLE IV-Mean systolic blood pressures and pulse rates of men and women at age 36 stratified by mothers' heights

\begin{tabular}{|c|c|c|c|}
\hline & \multicolumn{3}{|c|}{ Mother's height } \\
\hline & $\begin{array}{l}\leqslant 62 \text { in } \\
(157 \mathrm{~cm})\end{array}$ & $\begin{array}{c}63-64 \text { in } \\
(160-163 \mathrm{~cm})\end{array}$ & $\begin{array}{l}\geqslant 65 \text { in } \\
(165 \mathrm{~cm})\end{array}$ \\
\hline \multicolumn{4}{|l|}{ Men: } \\
\hline Systolic pressure ( $\mathrm{mm} \mathrm{Hg}$ ) (adjusted for weight) & $123.8(124 \cdot 0)$ & $123.4(123.4)$ & $121 \cdot 6(121 \cdot 3)$ \\
\hline Pulse rate (beats/min) (adjusted for height) & $71 \cdot 2(71 \cdot 0)$ & $71 \cdot 3(71 \cdot 3)$ & $70 \cdot 3(70 \cdot 6)$ \\
\hline \multicolumn{4}{|l|}{ Women: } \\
\hline Systolic pressure ( $\mathrm{mm} \mathrm{Hg}$ ) (adjusted for weight) & $118.0(118.0)$ & $116 \cdot 7(116 \cdot 7)$ & $117 \cdot 0(117 \cdot 0)$ \\
\hline Pulse rate (beats $/ \mathrm{min}$ ) (adjusted for height) & $73 \cdot 1(72 \cdot 8)$ & $73 \cdot 3(73 \cdot 4)$ & $72 \cdot 4(72 \cdot 6)$ \\
\hline
\end{tabular}

TABLE V-Mean systolic blood pressures and pulse rates of 10 year olds stratified by mothers' diastolic blood pressures

\begin{tabular}{lcccc}
\hline & \multicolumn{4}{c}{ Mother's diastolic pressure (mm Hg) } \\
\cline { 2 - 5 } & $<70$ & 70 & $71 \cdot 80$ & $>80$ \\
\hline Systolic pressure (mm Hg) (adjusted for weight) & $97 \cdot 4(97 \cdot 8)$ & $97 \cdot 9(98 \cdot 0)$ & $98 \cdot 5(98 \cdot 4)$ & $99 \cdot 5(99 \cdot 2)$ \\
Pulse rate (beats/min) (adjusted for height) & $77 \cdot 5(77 \cdot 5)$ & $77 \cdot 8(77 \cdot 9)$ & $77 \cdot 8(77 \cdot 9)$ & $78 \cdot 5(78 \cdot 6)$ \\
\hline
\end{tabular}

TABLE VI-Mean values of variables in 10 year olds and their mothers (adjusted for social class) in areas of England and Wales grouped according to cardiovascular mortality (ages 35-74, both sexes, 1968-78)

\begin{tabular}{|c|c|c|c|c|c|c|}
\hline & \multicolumn{5}{|c|}{ Group of areas } & \multirow[b]{2}{*}{$\begin{array}{l}\chi^{2} \text { For trenc } \\
(\mathrm{df}=1)\end{array}$} \\
\hline & $\begin{array}{l}1 \text { (Lowest } \\
\text { mortality) }\end{array}$ & 2 & 3 & 4 & $\begin{array}{l}5 \text { (Highest } \\
\text { mortality) }\end{array}$ & \\
\hline \multicolumn{7}{|l|}{ Mothers: } \\
\hline Height $(\mathrm{cm})$ & $162 \cdot 0$ & $162 \cdot 2$ & $161 \cdot 4$ & $161 \cdot 2$ & $160 \cdot 7$ & $29 \cdot 0^{\star \star}$ \\
\hline Diastolic blood pressure $(\mathrm{mm} \mathrm{Hg})$ & $71 \cdot 0$ & $71 \cdot 1$ & $71 \cdot 2$ & $72 \cdot 2$ & $71 \cdot 8$ & $9 \cdot 0^{\star}$ \\
\hline \multicolumn{7}{|l|}{ Children: } \\
\hline Systolic blood pressure $(\mathrm{mm} \mathrm{Hg})$ & $97 \cdot 8$ & 97.9 & $98 \cdot 5$ & $97 \cdot 8$ & $98 \cdot 4$ & 1.0 \\
\hline Pulse rate (beats/min) & $77 \cdot 0$ & $77 \cdot 2$ & $77 \cdot 5$ & $78 \cdot 5$ & $78 \cdot 3$ & $13 \cdot 4^{\star \star}$ \\
\hline Height $(\mathrm{cm})$ & 138.9 & $139 \cdot 2$ & $138 \cdot 6$ & $138 \cdot 5$ & $138 \cdot 0$ & $14 \cdot 6 \star \star \star$ \\
\hline Weight (kg) & $32 \cdot 9$ & $33 \cdot 1$ & $32 \cdot 7$ & $32 \cdot 8$ & $32 \cdot 6$ & $2 \cdot 0$ \\
\hline Birth weight (g) & 3333 & 3334 & 3318 & 3335 & 3316 & $0 \cdot 4$ \\
\hline
\end{tabular}

population size. Areas in the lowest cardiovascular mortality group were mostly in the south and east of the country, around London. Those in the highest mortality group were mostly in the north and west. Table VI shows the distribution of variables in the five groups. All values were adjusted to take account of the differing social class distributions in each group.

Among mothers heights fell from the lowest mortality group to the highest. There was no trend in systolic blood pressure but diastolic pressure rose from the lowest to the highest groups. Among children there was no significant trend in systolic pressure. There was, however, a clear trend of increasing pulse rate from the lowest to the highest mortality groups. This trend was little affected by adjustment for height, which fell from the lowest to the highest groups.

\section{Discussion}

Our analysis was based on two large samples of children and adults born in Britain and followed up from birth. These provide unique data for examining the relation between intrauterine influences and subsequent blood pressure and pulse rate.

Blood pressure and pulse rate correlated with each other both at 10 and 36 years of age. Blood pressure was higher in men than women but little different in boys and girls. Pulse rates were on average $2 \cdot 1$ beats $/ \mathrm{min}$ higher in women than men and 3.1 beats/min higher in girls than boys. Blood pressure showed the well known association with body weight. ${ }^{12}$ Pulse rate was inversely related to height, as might be expected from the general inverse relation between heart rate and body size in mammals. ${ }^{13}$

Both at 10 years of age (table I) and more strongly at age 36 (table II) systolic blood pressure was inversely related to birth weight. This was independent of current weight. Systolic blood pressure was also inversely related to maternal height (table IV) and positively related to maternal blood pressure (table V). Our data may underestimate the association of blood pressure and birth weight. Blood pressure measurements were not automated and were therefore subject to observer variation, and results were often rounded to the nearest $10 \mathrm{~mm} \mathrm{Hg}$. The spread of diastolic pressures was less than that of systolic pressures and rounding had a greater effect. This may explain the lack of associations with diastolic pressure. At both 10 and 36 years pulse rate was only weakly related to birth weight and was not related to maternal height (table IV). It was, however, positively related to maternal blood pressure (table V).

An inverse relation between blood pressure and birth weight has been recorded previously in two groups of children. Among 143 children in Aberdeen who weighed between 2001 and $2500 \mathrm{~g}$ at birth the systolic and diastolic pressures at age 10 were higher than in a group of controls. ${ }^{14}$ Among 692 children born in Dunedin, New Zealand, systolic pressure at 7 years was inversely related to birth weight. ${ }^{15}$ To our knowledge the relation of birth weight to adult blood pressure has not been examined in any other set of data, except for a small retrospective study of 77 young men. ${ }^{16}$ This inverse relation was not due to shortened gestation (table III) and may therefore be attributed to reduced fetal growth. Though the differences in mean systolic pressures were only $2 \mathrm{~mm} \mathrm{Hg}$ between adults in the lowest and highest birthweight groups (table II), small differences in the population distribution of risk factors may have large effects on disease mortality. Available data suggest that a lowering of the blood pressure distribution by $10 \mathrm{~mm} \mathrm{Hg}$ would correspond to a $30 \%$ reduction in total attributable mortality. ${ }^{17}$ Birth weight is an indicator of many intrauterine influences. The magnitude of the intrauterine effect on 
blood pressure cannot be deduced from the size of the relation of blood pressure with birth weight.

The inverse association between blood pressure and maternal height (table IV) is consistent with the known relation between shorter maternal stature and reduced fetal growth. ${ }^{18}$ The relation of blood pressure with birth weight was independent of the relation between blood pressure and maternal blood pressure (table V). This is consistent with the known lack of an association between maternal blood pressure and birth weight other than in severe pre-eclampsia. ${ }^{1819} \mathrm{~A}$ relation between blood pressure and maternal blood pressure has been recorded before. ${ }^{20}$ The relation between blood pressure and other maternal variables known to influence fetal growth - for example, age and parity is being examined.

Analyses on blood pressure at age 36 showed that the relation with birth weight was independent of two possible confounding variables-namely, cigarette smoking and the subjects' parity. ${ }^{10}$ Other than current weight, which our analysis took into account, we know of no variables which might confound the relation of birth weight with blood pressure in childhood. We conclude that this relation is evidence that the intrauterine environment influences blood pressure and pulse rates in later life. Further studies being carried out in different areas of Britain will clarify the role of other variables in this relation.

There are several possible mechanisms linking an adverse intrauterine environment with higher blood pressure through an effect on fetal growth. Pressure in the fetal circulation might be raised as a method of maintaining placental perfusion, and the raised pressures may persist after birth. ${ }^{16}$ Retardation of intrauterine growth may lead to accelerated postnatal growth that is accompanied by an accelerated increase in blood pressure. ${ }^{21}$

A link between the intrauterine environment and adult blood pressure might explain part of the geographical variation in death rates from cardiovascular disease within Britain. These variations are known to correlate with differences in mean systolic pressure in middle aged men. ${ }^{22}$ The evidence that past differences in the intrauterine environment contributed to them rests on the close geographical relation between current cardiovascular mortality throughout England and Wales and past neonatal and maternal mortality 60 and more years ago. ${ }^{5623}$ Recent comparison of birth weights during 1912-38 in Preston and London-areas with high and low neonatal and maternal mortality in the past-supports considerable anecdotal evidence that fetal growth was less in the areas with higher mortality. Mean birth weight in Preston was $289 \mathrm{~g}$ below that in London (unpublished data).

Our analysis of children born during 1970 shows that there are no longer large geographical differences in birth weight. Among the mothers, however, those living in areas with high cardiovascular mortality were on average shorter and had higher diastolic pressures at first attendance at the antenatal clinic (table VI). Children in areas with high mortality were shorter and had higher pulse rates. These differences between areas were independent of social class. Only small geographical differences in children's blood pressures were recorded. In a recent survey in nine British towns, however, the mean pressures of children aged 5 to 7 , measured with an automated recorder, were higher in towns with higher cardiovascular mortality. ${ }^{24}$

It may be expected that despite general improvements in the growth and development of girls, differences in the intrauterine environment from place to place will take several generations to disappear. The stability of fetal growth rates through successive generations has been shown by the positive correlation between the birth weight of mothers and their babies. ${ }^{25}{ }^{26}$ The geographical differences in the heights of mothers who had babies in 1970 and the differences in the pulse rates of their children at 10 years of age suggest that differences in the intrauterine environment predisposing to differences in blood pressure and cardiovascular mortality persist in Britain.

We are grateful to the British Heart Foundation for grants to JG for analyses on the 1970 cohort.

1 Tanner J, Healy M, Lockhart R, MacKenzie J, Whitehouse R. Aberdeen growth study. 1 . The prediction of adult body measurements from measurements taken each year from birth to 5 years. Arch Dis Child 1956;31:372.

2 Waaler HT. Height, weight and mortality. The Norwegian experience. Acta Med Scand 1984;679(suppl): 1-56.

Notkola V. Living conditions in childhood and coronary heart disease in adulthood. Helsinki: Finnish Society of Science and Letters, 1985.

4 Marmot MG, Shipley MJ, Rose G. Inequalities in death - specific explanations of a general pattern? Lancet 1984 ; i: 1003-6.

5 Barker DJP, Osmond C. Infant mortality, childhood nutrition and ischaemic heart disease in England and Wales. Lancet 1986; i: 1077-81.

6 Barker DJP, Osmond C. Death rates from stroke in England and Wales predicted from past maternal mortality. BrMed f 1987;295:83-6.

7 Chamberlain R, Chamberlain G, Howlett BC, Claireaux A. British births. Vol 1. The first week of life. London: Heinemann, 1975.

Vol 1 . The first week of life. London: Heinemann, 1975 .
8 Butler NR, Golding J. From birth to five: a study of the health and behaviour of Britain's five year olds. Oxford: Pergamon Press, 1986.

9 Butler NR, Golding J, Haslum M, Stewart-Brown S. Recent findings of the 1970 child health and education study: preliminary communication. $f R$ Soc Med 1982;75:781-4.

10 Wadsworth MEJ, Cripps HA, Midwinter RE, Colley JRT. Blood pressure in a national birth cohort at the age of 36 related to social and familial factors, smoking, and body mass. Br Med f 1985;291:1534-8.

11 Gardner MJ, Winter PD, Barker DJP. Atlas of mortality from selected diseases in England and Wales 1968-78. Chichester: John Wiley, 1984.

12 Szklo M. Epidemiologic patterns of blood pressure in children. Epidemiol Rev 1979:1:143-69.

13 Schmidr-Nielsen K. Scaling. Why is animal size so important? Cambridge: Cambridge University Press, 1984.

14 Cater J, Gill M. The follow-up study: medical aspects. In: Illsley R, Mitchell $\mathrm{RG}$, eds. Low birth weight, a medical psychological and social study. RG, eds. Low binh weight, a medical

15 Simpson A, Mortimer JG, Silva PA, Spears G, Williams S. In: Onesti G, Kim KE, eds. Hypertension in the young and old. New York: Grune and Stratton, KE, eds. $H y p$
1981:153-63.

16 Gennser G, Rymark P, Isberg PE. Low birth weight and risk of high blood pressure in adulthood. Br Med F 1988;296:1498-9.

7 Rose G. Sick individuals and sick populations. Int $f$ E pidemiol 1985;14:32.

18 Butler N, Alberman ED. Second report of the 1958 British perinatal mortality survey. Edinburgh and London: Livingstone, 1969.

19 Baird D, Thomson AM, Billewicz WZ. Birth weight and placental weight in pre-eclampsia. Fournal of Obstetrics and Gynaecology of the British Empire 1957;64:370-2.

20 Zinner SH, Rosner B, Oh W, Kass EH. Significance of blood pressure in infancy: familial aggregation and predictive effect on later blood pressure. Hypertension 1985;7:411-6.

21 Ounsted MK, Cockburn JM, Moar VA, Redman CWG. Factors associated with the blood pressures of children born to women who were hypertensive during pregnancy. Arch Dis Child 1985;60:631-5.

22 Shaper AG, Pocock SJ, Walker M, Cohen NM, Wale CJ, Thomson AG. British regional heart study: cardiovascular risk factors in middle-aged men in 24 towns. Br Med $\mathcal{F}$ 1981;283:179-86.

23 Barker DJP, Osmond C, Law C. The intra-uterine and early postnatal origins of cardiovascular disease and chronic bronchitis. $f$ Epidemiol Community Health (in press.)

24 Whincup PH, Cook DG, Shaper AG, MacFarlane DJ, Walker M. Blood pressure in British children: associations with adult blood pressure and cardiovascular mortality. Lancet 1988;ii:890-3.

25 Ounsted MK. Familial trends in low birth weight. Br Med f 1974;iv: 163.

26 Little RE. Mother's and father's birth weight as predictors of infant birth weight. Paediatric and Perinatal Epidemiology 1987;1:19-31.

(Accepted 22 December 1988) 